\title{
The PRIME Lab external research program
}

Pankaj Sharma* and David Elmore

Department of Physics, Purdue University, West Lafayette, IN 47907 (U.S.A.)

Stephan Vogt

Department of Chemistry, Purdue University, West Lafayette, IN 47907 (U.S.A.)

Submitted to the $7^{\text {th }}$ International Conference on Accelerator Mass Spectrometry,

Tucson, Arizona, May 20-24, 1996

To be published in Proceedings of Section B of Nuclear Instruments and Methods

\section{ABSTRACT}

PRIME Lab has a multidisciplinary external research program with projects in geomorphology, hydrology, ocean science, planetary science, environmental science and biology.

\section{Introduction}

PRIME Lab is a national AMS facility for measurement of the long lived cosmogenic nuclides ${ }^{10} \mathrm{Be},{ }^{14} \mathrm{C},{ }^{26} \mathrm{Al},{ }^{36} \mathrm{Cl},{ }^{41} \mathrm{Ca}$, and ${ }^{129} \mathrm{I}$ [1]. Since its inception in 1991 we have chemically processed over 2000 samples and have measured over 5000 research samples. Currently there are a total of about 125 external users conducting research using AMS data obtained at PRIME Lab. There are about 20 internal and 160 external ongoing research projects. About $60 \%$ of the samples measured at PRIME Lab belong to the external research program and about $40 \%$ of these are prepared in the PRIME Lab chemistry laboratory. About $40 \%$ of the samples are measured under a special seed analyses program to attract new users and to allow them to obtain preliminary data for proposals.

The multidisciplinary research program is centered in areas of atmospheric science, ocean science, hydrogeology, planetary science, glacial chronology and geomorphology, soil science, archaeology, anthropology, environmental science, and biology. About $50 \%$ of the research projects are focused around applications of in-situ produced cosmogenic nuclides $\left({ }^{10} \mathrm{Be},{ }^{26} \mathrm{Al}\right.$ and ${ }^{36} \mathrm{Cl}$ ) for geomorphology and climate change. Applications include glacial chronology, erosion and paleolake shorelines; determining tectonic uplift rates and seismic hazards; dating of landslides, volcanic lava flows, rock art, and paleoearthquakes events.

Other research applications include: radionuclide fallout and mapping across the U.S.A.; soil dynamics and chronology; cosmic ray intensity variations; diagenesis of ferromanganese crusts; distribution of ${ }^{129} \mathrm{I}$ and carbon cycling in the oceans; groundwater tracing; assessment of low level and high level radioactive waste repositories; release of radioactivity from fuel reprocessing facilities and reactors; toxicity and uptake of Al by plants and animals; determination of neutron energy spectra from atomic bombs at Hiroshima and Nagasaki; and exposure histories and terrestrial ages of meteorites and tektites. A few examples are given below to indicate the breadth of the PRIME Lab external research program.

\section{Geomorphology}

\section{6}




\section{Cl production rates in terrestrial rocks}

Since ${ }^{36} \mathrm{Cl}$ is applicable to a wide variety of rock types and does not require mineral separation, there has been a rapid increase in the use of in-situ produced cosmogenic ${ }^{36} \mathrm{Cl}$ for geomorphological studies. To determine it's production rate, ${ }^{36} \mathrm{Cl}$ was measured in 33 rock samples having known exposure histories and ages [2]. The ${ }^{36} \mathrm{Cl}$ production rates were estimated by minimizing the squared deviations between the ${ }^{36} \mathrm{Cl}$ and independent ages, yielding the following production rates (applicable to surface at sea level and latitude $>60$ ).

Spallation and -production from $\mathrm{Ca}=2940+/-200$ atoms ${ }^{36} \mathrm{Cl}(\text { mole Ca) })^{-1} \mathrm{a}^{-1}$, Spallation from $\mathrm{K}=6020+\backslash-400$ atoms ${ }^{36} \mathrm{Cl}(\mathrm{mole}$ $\mathrm{K})^{-1} \mathrm{a}^{-1}$, Neutron production in air $=586+/-40$ fast neutrons $(\mathrm{g} \text { air })^{-1} \mathrm{a}^{-1}$. The new production parameters on $\mathrm{Ca}$ and thermal neutron activation are in good agreement with previous results, but that for $\mathrm{K}$ spallation is $\sim 50 \%$ larger [3].

\section{Fault Scarp}

Fault scarps contain information on timing and frequency of paleoseismic activity. Dating is important to assess the stability of an area. A series of samples from a late Quaternary bedrock fault scarp at Lake Hebgan, Montana have been dated by ${ }^{36} \mathrm{Cl}$ build up [4]. The scarp shows multiple surface ruptures as bands of similar weathering characteristics in limestone bedrock. Cosmogenic ${ }^{36} \mathrm{Cl}$ dating of the fault has been shown to be feasible. The ${ }^{36} \mathrm{Cl}$ ages for the bedrock fault face are consistent with seismic stratigraphy, i.e. they increase consistently and predictably toward the top of the face. This method promises to become an important tool for quantitative paleoseismology.

\section{Petroglyphs}

Petroglyphs (ancient rock carvings) in Foz Coa Valley, Portugal, were discovered during construction, which is presently halted, of a hydroelectric dam. They are now a focus of an international archaeological controversy. Stylistic methods suggest Paleolithic age (15-750 ka) while geomorphic observations suggest Holocene age $(<20 \mathrm{ka})$. Surface exposure ages using ${ }^{36} \mathrm{Cl}$ have been determined for samples collected from rock panels. Organic carbon on rock panels has also been dated by ${ }^{14} \mathrm{C}$ method. ${ }^{36} \mathrm{Cl}$ ages range from 40-270 ka indicating that engraved panels were available for painting for at least $40 \mathrm{ka}$ [5]. The hydraulic gradient indicates that the landscape is relatively stable. The erosion rates are expected to be low because of the relatively resistant nature of the rock (schist). Comparison of ${ }^{36} \mathrm{Cl}$ and ${ }^{14} \mathrm{C}$ indicate that organic carbon on the Coa rock faces is an open system and radiocarbon can provide only minimum ages.

\section{Oceanography}

\section{Ferromanganese crust}

A determination of growth rates of ferromanganese deposits can help to elucidate the nature of their origin. The long-lived ${ }^{10} \mathrm{Be}$ $(1.5 \mathrm{Ma})$ is a most suitable radionuclide for dating these deposits. The concentration of ${ }^{10} \mathrm{Be}$ has been measured in nine stratigraphic layers of a Pacific ferromanganese crust (KK84-04-28-05; Station 64; PD-08 Sample\#2; thickness 73 mm) recovered from an unmanned seamount in the Hawaiian Archipelago (24 11' N, 174 1' W; water depth 1100-1475 meters). Concentrations of

${ }^{10} \mathrm{Be}$ vary from 1.3 to $160 \times 10^{8}$ atoms $/ \mathrm{g}$. The changes in ${ }^{10} \mathrm{Be}$ and ${ }^{10} \mathrm{Be} / 9 \mathrm{Be}$ have been interpreted as changes in growth rates. Initially, the crust started growing at a slow rate of 3-5 $\mathrm{mm} \mathrm{Ma}^{-1}$ (depth 48-73 mm) followed by a rapid growth period (29-48 $\mathrm{mm}$ ) and more recent growth at a slower rate of $3 \mathrm{~mm} \mathrm{Ma}^{-1}$ (depth 0-29 $\mathrm{mm}$ ). It appears that the crust is of the Miocene age.

\section{${ }^{129}$ I as a new oceanography tracer}

Nuclear weapon manufacturing, power generation and fuel reprocessing activities have released large quantities of ${ }^{129} \mathrm{I}$ levels to the environment [6]. Iodine is biophilic and has potential to be used as a tracer for marine organic matter and ocean currents. Depth profiles of ${ }^{129} \mathrm{I}$ have been measured in the Gulf of Mexico and Mid-Atlantic Bight. Surface values of ${ }^{129} \mathrm{I} / \mathrm{I}$ in the Gulf of 
Mexico waters are about 60 times higher than pre-nuclear era levels and decrease steadily to a background value of $1.2 \times 10$ at a depth of about $2000 \mathrm{~m}$ near the bottom. In contrast, a subsurface peak has been observed at a depth of 1000-1500 m in the middle of Atlantic Bight followed by a steady increase below $2000 \mathrm{~m}$. The subsurface increase below $2000 \mathrm{~m}$ water depth is attributed to the Deep Western Boundary Current, and the minor maximum at 1000-1500 $\mathrm{m}$ is due to mixing of water from Labrador Sea [8]. The depth distribution of ${ }^{129}$ I in the Mid-Atlantic Bight follows the trends of chlorofluorocarbon F-11.

\section{Groundwater tracing and dating}

\section{Kobe earthquake, Japan}

Concentrations of radon, chloride and sulfate fluctuated in ground water pumped from two wells located about $20 \mathrm{~km}$ east of the epicenter before the disastrous M7.2 Hyogo-ken Nanbu earthquake in southwestern Japan of 17 January 1995 [9]. The sudden decrease in ${ }^{222} \mathrm{Rn}$ one week before the earthquake may be due to sealing of microcracks and then the subsequent increase due to release of the strain before the fault line ruptured. The ${ }^{36} \mathrm{Cl} / \mathrm{Cl}$ ratio dropped significantly $(30 \%)$ just before the earthquake. The decrease in the ratio could be due to (1) enhanced rock dissolution caused by the formation of microcracks and/or (2) addition of old ground water having low ${ }^{36} \mathrm{Cl} / \mathrm{Cl}$.

\section{${ }^{36}$ Cl mapping}

Chlorine-36 is used for ground water dating and tracing. In most dating applications it is essential to know the initial ${ }^{36} \mathrm{Cl} / \mathrm{Cl}$ ratio at time $\mathrm{t}=0$ for establishing a baseline value. The purpose of this study is to determine the geographic variations of ${ }^{36} \mathrm{Cl}$ in water which has entered the subsurface between 50 a and $10 \mathrm{ka} \mathrm{BP}$. The information is needed to replace old maps based on simple models. We have been sampling and measuring ${ }^{36} \mathrm{Cl}$ in soil cores and ground water that has tritium concentrations below $2 \mathrm{TU}$ to avoid any anthropogenic contamination and has ages $<10 \mathrm{ka}$ to avoid probable shifts in production rates. The available data in the literature are being compiled for a revised provisional map of ${ }^{36} \mathrm{Cl} / \mathrm{Cl}$ ratios in groundwater in the continental U.S.A. to be used as baseline values for proper interpretation of the data [10].

\section{Yucca Mountain, Nevada}

Yucca Mt. is being investigated as a potential site for a high level radioactive waste repository. A major aspect of the site's suitability for isolating the waste concerns the rates and pathways of water movement through the unsaturated zone above and below the potential repository horizon. Samples have been measured for $\mathrm{Cl}, \mathrm{Br}$ and ${ }^{36} \mathrm{Cl}$ from the Exploratory Studies Facility (ESF) tunnel (4 km length) and from boreholes to ascertain the role of faults and fractures as preferential flow paths and to estimate residence times of groundwater [11]. The bomb-pulse signal is used to decipher the presence of fast transport paths. All ESF samples show ${ }^{36} \mathrm{Cl} / \mathrm{Cl}$ signals ranging from 1 to 3 times the present-day background value, which is consistent with the expectation that the input varied within this range. Uncertainties in temporal variations in the input ratio presently limit precision of ground-water travel times. Bomb-pulse ${ }^{36} \mathrm{Cl}$ occurs at a few distinct fractured and/or faulted zones, indicating that at least a small proportion of the water at these locations is less than 50 years old.

\section{Packrat middens}

The ${ }^{36} \mathrm{Cl} / \mathrm{Cl}$ input function with time is also needed for proper interpretation of data of groundwater data. Past variations in this function are being determined by measuring ${ }^{36} \mathrm{Cl} / \mathrm{Cl}$ ratios in ${ }^{14} \mathrm{C}$ dated packrat midden samples from Nevada. Consistent with other data from the published literature, these results support the hypothesis that the meteoric ${ }^{36} \mathrm{Cl} / \mathrm{Cl}$ ratio during the past $30 \mathrm{ka}$ was significantly higher than at present [12].

\section{Distribution of environmental radioactivity}

\section{Idaho Falls, Idaho}


Radionuclides released from bomb testing, fuel reprocessing plants, and reactors are used for monitoring environmental contamination and for tracing of groundwater. The purpose of this project is to reconstruct historical development of the radioactive waste-plume through time and space and to construct the 2-D flow motion of groundwater at the Idaho National Engineering Laboratory, Idaho Falls, ID, USA. Concentrations of ${ }^{36} \mathrm{Cl}$ and ${ }^{129} \mathrm{I}$ have been determined in soil cores, snow samples, ice cores, well waters and archived groundwater to document radioactive releases. Long-lived ${ }^{36} \mathrm{Cl}$ and ${ }^{129} \mathrm{I}$ are better tracers than short-lived tritium for long term monitoring of groundwater. The ${ }^{36} \mathrm{Cl}$ distribution in soil cores provided an infiltration rate of $\sim 0.7 \mathrm{~cm} \mathrm{a}^{-1}$. Ground water flow velocities $\sim 2 \mathrm{~m} \mathrm{~d}^{-1}$ have been calculated from first arrival time and distribution of ${ }^{36} \mathrm{Cl}$ at the Idaho Falls site [13].

\section{Ob river, Russia}

The Soviet Union has discharged large amounts of radioactivity [1.7 billion curies, Ref. 14] into the environment. These included direct discharges into lakes and rivers, accidental releases (e.g., Chernobyl), and inadequate management of radioactive waste resulting from reprocessing of spent fuel, as well as the large-scale injection of waste into the ground. The three most contaminated sites in Russia are Mayak, Tomsk-7 and Krasnoyarsk-26. Water samples collected from 5 stations along the $\mathrm{Ob}$ River system from headwaters in central Siberia to the Ob Gulf on the Kara Sea have been used to determine the concentrations of ${ }^{36} \mathrm{Cl}$ and ${ }^{129} \mathrm{I}$. Concentrations of these nuclides are several orders of magnitude higher in samples collected near the production reactor, reprocessing, weapons design laboratory, and uranium enrichment facilities. The US Department of Energy and the Ministry of Atomic Energy of the Russian Federation have agreed to share waste management and clean-up technologies.

\section{West Valley, New York}

An extensive investigation has been conducted to measure levels of anthropogenic ${ }^{129} \mathrm{I}$ in water, soil, grass, and aquatic plant samples from near West Valley, New York [15]. The nuclear fuel reprocessing plant in West Valley is no longer operating. The ${ }^{129}$ I concentrations downstream from West Valley are on the order of $10^{11}$ atoms $\mathrm{L}^{-1}$. These higher signals could be traced as far as Lake Erie and possibly into Lake Ontario via Niagara River. Samples from the Finger Lakes regions are about 2-3 orders of magnitude lower $\left(10^{8}\right.$ atoms $\left.\mathrm{L}^{-1}\right)$ than the West Valley signal. Samples around two nuclear power plants (Ginna and 9-Mile Point) are indistinguishable from western New York background suggesting that operation of these power plants does not contribute significant ${ }^{129}$ I to the environment. Samples from eastern NY, Vermont and Canada have ${ }^{129}$ I concentrations on the order of $10^{7}$ atoms $\mathrm{L}^{-1}$. These results suggests that releases from the West Valley site have significantly raised ${ }^{129}$ I levels in the western New York region.

\section{Bomb-produced ${ }^{36} \mathrm{Cl}$}

Bomb-produced ${ }^{36} \mathrm{Cl}$ has been determined in a mid-latitude ice core from the Upper Fremont Glacier in the Wind River Range, Wyoming, U.S.A. The pre-bomb flux is in agreement with the mean global natural production flux for ${ }^{36} \mathrm{Cl}$. The calculated flux for ${ }^{36} \mathrm{Cl}$ in ice deposited in the late 1950's compares well with the flux reported for the Dye 3 ice core from Greenland [16]. It may now be possible to quantify the ${ }^{36} \mathrm{Cl}$ flux from nuclear-weapon tests archived in mid-latitude glacial ice to better understand the distribution and transport of this cosmogenic nuclide.

\section{Meteorites}

Determination of cosmogenic nuclides provides information on terrestrial ages, exposure ages, and conditions of exposure to cosmic rays. Interest in production rate systematics of iron meteorites has increased because laboratory simulation studies are underway to improve semi-empirical calculations. The systematics of noble gas production rates in iron meteorites have been a subject of many experimental studies while comparable studies of cosmogenic radionuclides are few in number. Chlorine-36 concentrations have been determined in 48 samples, including four samples of the Grant meteorite, from known shielding locations. The AMS results on the Grant meteorite span a narrower range than do those obtained earlier in 1960's by low-level counting (14-17 dpm kg-1 verses 11-20 dpm kg${ }^{-1}$ ). The new results on the Grant meteorite correlate very well with ${ }^{26} \mathrm{Al}$ and ${ }^{10} \mathrm{Be}$ and will be useful in checking theoretical production rate calculations. These measurements show the importance of shielding 
on $\mathrm{Cl}$ production in large meteorites. Bur Gheluai, Dalgety Downs, and Dhajala meteorites have a more complex irradiation history.

\section{Biology}

We are studying uptake and localization of $\mathrm{Al}$ in plants. Plants suffer nutrient deficiency and develop drought intolerance following acid rain. It has been suggested that the drought intolerance could be related to toxicity from $\mathrm{Al}$ released in acidic conditions. There is a general lack of understanding about the movement of Al across plasma membranes. Earlier attempts to study transfer rates using stable $\mathrm{Al}$ and graphite atomic absorption spectrophotometry (GFAAS) have failed due to large backgrounds. Aluminum-26 is being used as a tracer to measure the uptake of $\mathrm{Al}$ in cell walls, cytoplasm and vacuole in plants cells of Chara Corallina. These results are compared with ${ }^{27} \mathrm{Al}$. There is agreement between ${ }^{27} \mathrm{Al}$ (GFAAS) and ${ }^{26} \mathrm{Al}$ (AMS) uptake by the cell walls. Uptake by cytoplasm is not feasible by ${ }^{27} \mathrm{Al}$ (GFAAS) but it is measurable by ${ }^{26} \mathrm{Al}$ (AMS). About $0.1 \%$ of the $\mathrm{Al}$ binds in cytoplasm compared to the cell wall. It has been found that Al uptake is biphasic in nature, i.e. rapid initial uptake (passive uptake) followed by slow linear uptake (metabolism dependent). In the future we plan to isolate the vacuolar fraction and measure the uptake by vacuoles.

\section{Acknowledgments}

We like to thank the following people for their PRIME Lab external research contributions: Douglas Hunter and Paul Bertsch of Savannah River Ecology Laboratory; June Fabryka-Martin and Beiling Liu of Los Alamos National Lab; Udo Fehn and Usha Rao of University of Rochester; H. Wakita of University of Tokyo; Marek Zreda and Stan Davis from University of Arizona; DeWayne Cecil of United States Geological Survey; Thomas Beasley of Department of Energy; Montgomery Flinsch, Mitch Plummer, and Fred Phillips, New Mexico Tech; Greg Herzog of Rutgers University; Gary McMurtry of University of Hawaii; Ron Dorn of Arizona State University at Tempe; Peter Santschi, David Schink, and Jean Moran of Texas A\&M University. PRIME Lab is supported by the Geosciences Directorate of the National Science Foundation.

\section{References}

[1] D. Elmore, M. Lipschutz, X. Ma, T. Miller, K. Mueller, M.Perry, F. Rickey, P. Sharma, P. Simms, S. Vogt, this volume

[2] F.M. Phillips, M.G. Zreda, M. Flinsch, D. Elmore and P. Sharma, J. Geophys. Res. Letts., 23(1996)949

[3] M.G. Zreda, F.M. Phillips, D. Elmore, P.W. Kubik, P. Sharma, and R.I. Dorn, Earth Planet. Sci. Letts., 105(1991)94

[4] M.G. Zreda, J.S. Noller, W.R. Lettis, EOS (1995) F685 [5] M.R. Flinsch, F.M. Phillips, EOS (1995) F689 [6] F. Yiou,G.M.

Raisbeck, Z.Q. Zhou and L.R. Kilius, Nucl. Instr. and Methods in Physics Research, B92 (1994)436

[7] D.R. Schink, P.H. Santschi, O. Corapcioglu, P. Sharma and U. Fehn, Earth Planet. Sci. Letts. 135(1995)131

[8] P.H. Santschi, D.R. Schink, O. Corapcioglu, S. Oktay-Marshall, U. Fehn and P. Sharma, Deep Sea Research (1996), in press

[9] U. Tsunogai and H. Wakita, Science, 269(1996)61

[10] S. Davis, M.G. Zreda, D. Cecil and P. Sharma, (1996), in preparation

[11] J.T. Fabryka-Martin, P.R. Dixon, S. Levy, B. Liu, H.J. Turin, and A.V. Wolfsberg, Summary Report of Chlorine-36 Studies: Systematic Sampling for Chlorine-36 in the Exploratory Studies Facility, Los Alamos National Laboratory Report LA-UR-961384, 1996.

[12] F.M. Phillips, P. Sharma, and P. Wigand, EOS (1991)72 
[13] L.D. Cecil, S.K. Sharpe, R.J. Drimmie, E.A. Sudicky, J.A. Cherry, P. Sharma, D. Elmore and S. Vogt, Abstract volume American Chemical Society 209th Meeting, Anaheim, CA, April 2-6 (1995), Abstract \# NUCL 68

[14] D. Bradley, C.W. Frank, and Y. Mikerin, Physics Today, April (1996) 41

[15] U. Rao, R. Teng and U. Fehn, this volume

[16] L.D. Cecil and S. Vogt, this volume 